\title{
Plant community structure and diversity under grazing gradient in arid Mediterranean steppe of Algeria
}

\author{
S. Merdas ${ }^{1,2 *}$, A. Menad ${ }^{1}$,T. Mostephaoui ${ }^{2}$, B. Sakaa ${ }^{2}$ \\ ${ }^{1}$ Laboratory of biology and environment, Department of Biology and Ecology, Mentouri Brothers University - Constantine, \\ Ain El Bey, 25017 Constantine, Algeria \\ ${ }^{2}$ Centre of scientific and technical research on arid regions, BP $n^{\circ} 1682$ R.P 07000 Biskra-Algeria
}

Received 21 Jul 2016,

Revised 13 Nov 2016 ,

Accepted 16 Nov 2016

Keywords

$\checkmark$ Degradation,

$\checkmark$ diversity,

$\checkmark$ grazing,

$\checkmark$ protection,

$\checkmark$ conservation,

$\checkmark$ arid Mediterranean steppe.

saifieco@gmail.com;

Phone: (+213559092 656)

\begin{abstract}
Desertification is a worldwide concern; in Algeria, land degradation threats more than 20 million of steppe rangelands. Protection from grazing is a technique widely used as a management tool for the development of the steppes. The aim of this study is to investigate the effect of grazing on plant community structure and diversity. We conducted a comparative study of the plant community structure and diversity in grazed and ungrazed areas. We assessed soil surface conditions; vegetation, litter, bare ground, biological soil crusts and Stipa tenacissima cover. In addition, we quantified plant species diversity using species richness, Shannon diversity index, Simpson index and Evenness. Our results showed that grazing activities have largely reduced values of the vegetation cover and diversity in grazed areas. In addition, grazing activities affected plant community assemblages. The cover of the most dominant species (Stipa tenacissima), was not affected by grazing. Nevertheless, the protection from grazing increased significantly the species diversity of annual species and vegetation cover. This study highlights the importance of protection and conservation as an effective management tool for maintaining the plant community structure and diversity in threatened ecosystems.
\end{abstract}

\section{Introduction}

Land degradation is one of the most important problems affecting a wide range of ecosystems worldwide. The intensive exploitation of rangelands, under high stocking rates, is a driver of land degradation [1] and loss of biodiversity [2]. As well as anthropogenic factors playing a leading role in the organization of vegetation structures [3]. Grazing is the dominant land use in Northern Africa [4]. According to Aidoud and Touffet, 1996 [5], overgrazing is the principal factor of the degradation of plant communities in North Africa. In such situation, the understanding of the effect of grazing on plants species diversity and structure is an important topic for conservation purposes and management practices.

Steppe ecosystems in Algeria cover more than 20 million hectares [18]. The combination of many regressive processes, such as: woodcutting, wild fires, overstocking and clearing, have contributed to the present steppe conditions [19]. According to the biogeography, these steppe rangelands belong to the Mediterranean basin, one of the 25 biodiversity hotspots of the globe [20]. Mediterranean ecosystems are considered among the most vulnerable to global change [21]. These ecosystems have evolved under the long history of grazing, and over time, the various farming methods in these areas have shaped the landscapes and resources that are found there [1]. The evaluation of the effect of grazing on plant diversity and structure has been studied extensively in rangeland ecosystems [6-9]. In more humid environments (productive), grazing is predicted to increase species diversity. Whereas, in arid environments grazing can have a negative effect on diversity [10]. In semi-arid Mediterranean grasslands, grazing reduces plant diversity [11]. North African arid grasslands, exhibits the same trend where grazing has decreased diversity [12-14].

The study of the change in plant community structure and diversity over grazing gradient can help in the understanding of ecosystem response to management practices [15]. Although, vegetation is an important indicator for the assessment of overall ecosystem's function [16] and conservation [17].

For the prospect of conservation and management, Algerian authorities have undertaken a program to the development of rangelands, by the creation of the High Commission for the Development of Steppe (HCDS) 
belonging to the Ministry of Agriculture and Rural development in 1981. Grazing exclosure is a management technique used widely by the HCDS since 1994 [13], and the main objectives of the HCDS were regulation of pastoral activity, protection and management of rangelands. Previous studies were conducted to evaluate the importance of exclosure as a management tool for the biological recovery and ecological restoration of the steppe e.g. [13, 22]. In these studies, it is reported that exclosure technique increased plant diversity and vegetation cover, and authors focused only on the global vegetation cover and diversity of all recorded plants. However, it is widely recommended to study also functional group diversity [7, 23, 24, 25]. Detecting land degradation change is better pronounced at the level of functional groups than at species level [25].

In this context, our study conducted in arid steppe rangelands of Algeria has two specific objectives: (1) to assess the effect of grazing on plant species diversity, as well as identifying which functional group of species is more affected by grazing activity. In addition (2) to evaluate the effect of grazing on soil surface characteristics (cover parameters) in arid Mediterranean steppe representing an important ecosystem providing multiple services.

\section{Materials and methods}

\section{1. Study area}

The study was conducted in central steppe rangelands of Algeria, in the western part of Hodna basin. Study sites were located in five districts (Ain El Hadjel, Benzouh, Sidi Ameur, Tamsa and El Hamel), belonging to the Wilaya (province) of Msila (Figure 1). The average annual temperature is between 17 and $21^{\circ} \mathrm{C}$ and average annual rainfall ranges from 200 to $400 \mathrm{~mm}$, the largest amount of rainfall occurs during spring and fall.

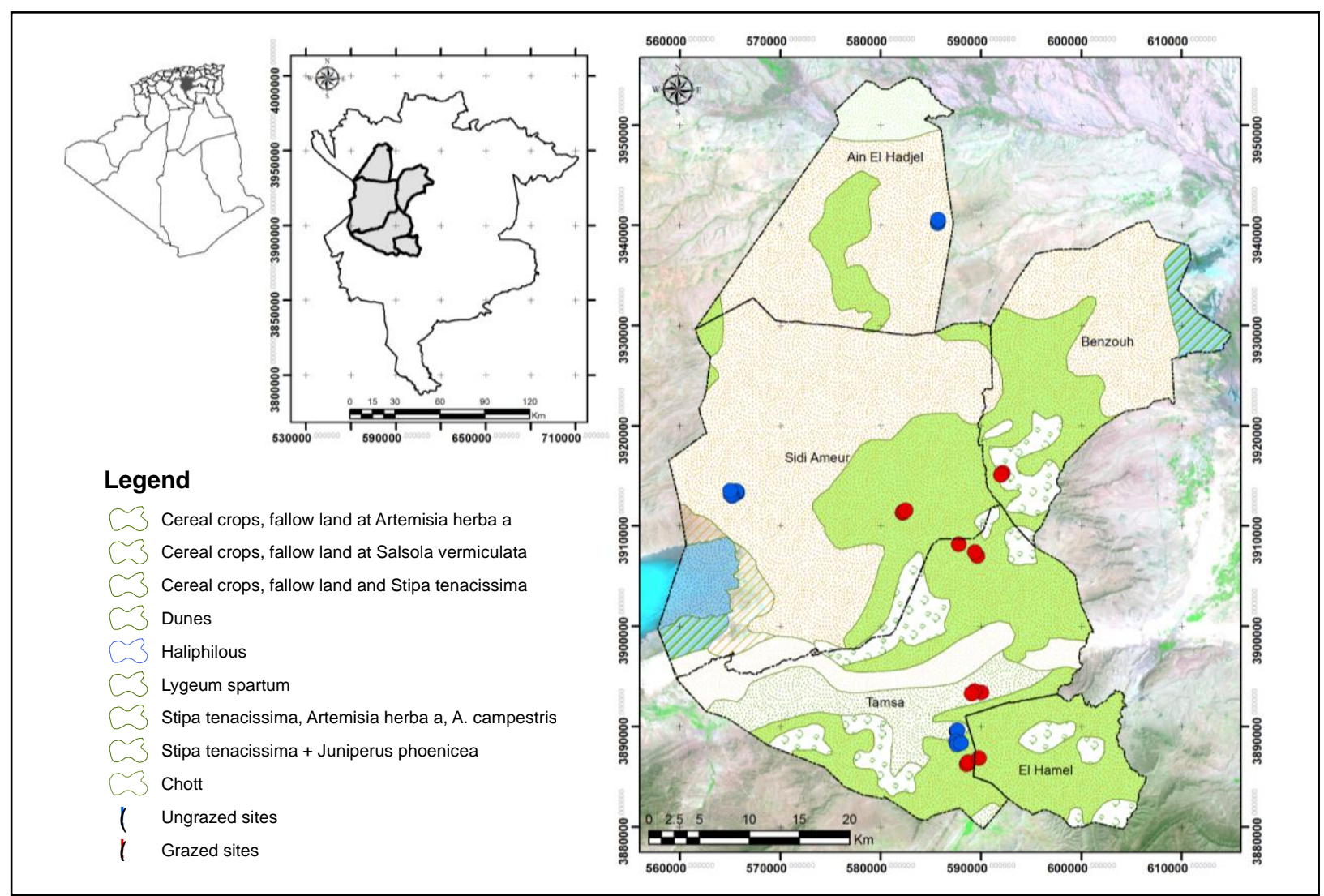

Figure 1: Vegetation map of the study area, with locations of sampling sites

(System coordinates WGS 1984 UTM Zone 31N)

Land use is characterized by the dominance of livestock grazing system. According to Halitim,1988 [26] soils are characterized by, humiferous rendzinas soils, calcareous brown soils and encrusted gypsum soils. The vegetation is dominated by perennial grass Stipa tenacissima associated with Artemisia herba alba, Artemisia campestris and Juniperus phoenicea in high slopes. Cereal crops and fallows associated with Stipa tenacissima, Artemisia herba alba and Salsola vermiculata represents the degraded vegetation in the study area (Figure 1).

We used the method provided by [27] to estimate the animal density in the five districts. The data were obtained from the agricultural services of the province of Msila. The density is expressed in the sheep equivalent (a sheep 
with its cubs) per hectare (sp.eq/ha). We multiply the number of each type of livestock by its sheep equivalent (sheep $\times 1$, cattle $\times 5$, and goats $\times 0.8$ ); the total sum of these values represents the total number of sheep equivalents. The density is obtained by dividing the total number of sheep equivalents by the area of rangelands in each district. The density in the district of Ain El Hadjel was 4.55 sp.eq/ha, 1.95 in Sidi Ameur, 1.25 in Tamsa, 10.38 in El Hamel and 0.74 in Benzouh. According to [27] rangelands can meet the needs of livestock at the density level of $0.33 \mathrm{sp} . e q / \mathrm{ha}$. This indicates that rangelands in the five districts are subjected to a high density of livestock.

\section{2. Vegetation survey}

All data were collected between April and May 2014, corresponding to the high period of growth of vegetation. In total, 30 transects with $200 \mathrm{~m}$ length were sampled, and have the similar topographic conditions (open and flat field site), 15 transects were protected from grazing and 15 were freely grazed. To estimate plant abundance, richness and soil surface conditions, we used the Point-Intercept Method [28]. In this method, we recorded at 20 $\mathrm{cm}$ intervals the identity of plant species and soil surface conditions (cover) for each transect. Plant nomenclature followed Quézel and Santa, 1962; 1963 [29, 30].

\section{3. Data analysis}

To assess which group of species is affected by grazing, plant species recorded in this study were grouped based their life span, to annual forbs, perennial forbs, annual grass, perennial grass, and shrub species. Then measures of diversity were calculated for each species group. The species richness was quantified by the count of all species recorded in each transect [31]. To estimate plant species diversity, we calculated the Shannon-Wiener index $(\mathrm{H})$ [32]. Species ecological dominance was calculated by the Simpson index (D) and Evenness (E) [33]. One-way analysis of variance (ANOVA) procedure was used to test the significant differences in diversity parameters and soil surface conditions between protected and grazed areas. All analyses were performed in $\mathrm{R}$ software [34]. Soil surface conditions (cover), were estimated for each surface component (vegetation cover, annual cover, perennial cover with Stipa tenacissima, perennial cover without Stipa t., Stipa t. cover, biological soil crusts (BSCs) cover, litter cover, and bare soil cover) by weighting the number of hits (records) of each soil surface condition to a total cover.

\section{Results}

In this study of arid rangelands in central steppe ecosystems, Algeria, we recorded 101 plant species for the 30 transects (Appendix 1). Most of the species belong to the Asteraceae family (26 species), followed by Poaceae (18 species) and Fabaceae (eight species) (Figure 2). In protected areas, the average of floristic transects contained 30 species (range 21-37). Whereas, in grazed areas, the average of floristic transects contained 19 species (range 10-26).

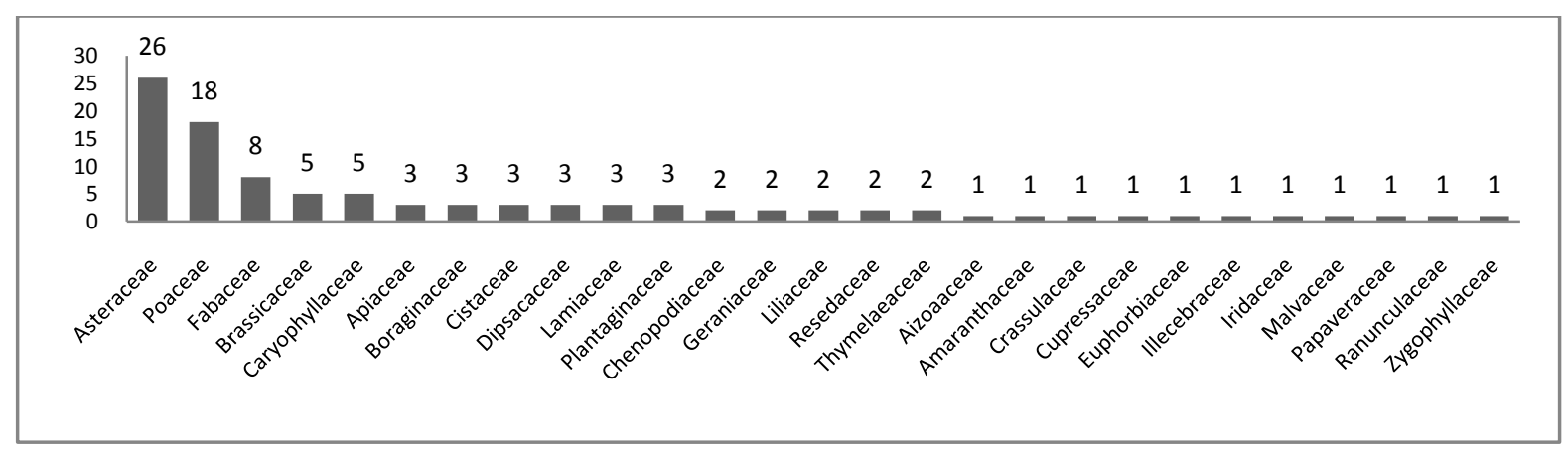

Figure 2: Number of species recorded in each family.

\section{1. Plant community diversity}

For annual forbs, species richness differed significantly between grazed and protected areas, the mean richness value in protected areas was 18 species, and for grazed areas, it was eight species ( $\left.\mathrm{S} F_{1,28}=67.46, P<0.0001\right)$. Grazing activity affected significantly diversity indices Shannon index $\left(\mathrm{H} F_{1,28}=17.28, P<0.0001\right)$ and Simpson index (D $\left.F_{1,28}=4.63, P<0.0001\right)$, but Evenness $\left(\mathrm{E} F_{1,28}=0.55, P<0.464\right)$ there are no significant differences. For perennial forbs, only Shannon index was significantly different between grazed and protected areas, whereas, other diversity measures were not. For other functional groups (Annual Grass, Perennial Grass, and shrubs), no significant differences were found (Table 1). 
Table 1. Mean values of diversity indices between grazed and protected areas.

\begin{tabular}{|c|c|c|c|}
\hline Parameters & Protected & Grazed & Signification \\
\hline \multicolumn{4}{|l|}{ Annual forbs } \\
\hline$S$ & $18(3.95)$ & $8(2.73)$ & 0.0001 \\
\hline $\mathrm{H}$ & $1.95(0.38)$ & $1.42(0.30)$ & 0.0001 \\
\hline $\mathrm{D}$ & $0.76(0.11)$ & $0.67(0.09)$ & 0.040 \\
\hline $\mathrm{E}$ & $0.67(0.12)$ & $0.70(0.09)$ & 0.464 \\
\hline \multicolumn{4}{|l|}{ Perennial forbs } \\
\hline$S$ & $5(1.95)$ & $4(1.57)$ & 0.092 \\
\hline $\mathrm{H}$ & $1.06(0.33)$ & $0.79(0.37)$ & 0.046 \\
\hline $\mathrm{D}$ & $0.55(0.13)$ & $0.44(0.21)$ & 0.118 \\
\hline $\mathrm{E}$ & $0.71(0.13)$ & $0.71(0.26)$ & 0.973 \\
\hline \multicolumn{4}{|l|}{ Annual Grass } \\
\hline S & $3(1.45)$ & $3(1.24)$ & 0.987 \\
\hline $\mathrm{H}$ & $0.47(0.50)$ & $0.50(0.40)$ & 0.833 \\
\hline $\mathrm{D}$ & $0.25(0.26)$ & $0.29(0.23)$ & 0.670 \\
\hline $\mathrm{E}$ & $0.53(0.34)$ & $0.61(0.27)$ & 0.563 \\
\hline \multicolumn{4}{|l|}{ Perennial Grass } \\
\hline $\mathrm{S}$ & $2(0.67)$ & $2(0.74)$ & 0.209 \\
\hline $\mathrm{H}$ & $0.19(0.19)$ & $0.17(0.22)$ & 0.848 \\
\hline $\mathrm{D}$ & $0.10(0.12)$ & $0.09(0.14)$ & 0.947 \\
\hline $\mathrm{E}$ & $0.26(0.25)$ & $0.33(0.30)$ & 0.561 \\
\hline \multicolumn{4}{|l|}{ Shrubs } \\
\hline S & $2(1.16)$ & $2(1.30)$ & 0.774 \\
\hline $\mathrm{H}$ & $0.45(0.37)$ & $0.53(0.37)$ & 0.541 \\
\hline $\mathrm{D}$ & $0.40(0.32)$ & $0.39(0.25)$ & 0.950 \\
\hline $\mathrm{E}$ & $0.49(0.37)$ & $0.64(0.29)$ & 0.255 \\
\hline
\end{tabular}

S: richness, H: Shannon index, D: Simpson index, E: Evenness, numbers between brackets indicates standard deviation, numbers in bold indicates no significance of ANOVA tests.

\section{2. Plant community structure}

The global vegetation cover changed significantly between the two treatments $\left(F_{1,28}=22.01, P<0.0001\right)$, the recovery rate was $50.69 \%$ in protected areas compared with $36.95 \%$ in grazed areas. The annual species cover was $27.27 \%$ in protected habitats, while in grazed one it was $13.37\left(F_{1,28}=18.84, P<0.0001\right)$. Perennial cover including Stipa tenacissima, did not differ between treatments $\left(F_{1,28}=0.004 \quad P<0.952\right), 23.43 \%$ for protected areas and $23.59 \%$ in grazed areas. Also, no significant differences were observed for perennial cover without Stipa $\left(F_{1,28}=0.06, P<0.809\right)$, the cover was $7.97 \%$ in protected habitats and $8.63 \%$ in grazed ones. The cover of Stipa tenacissima was $15.38 \%$ in protected areas compared to $15.04 \%$ in grazed areas, no significant differences were recorded between the two treatments $\left(F_{1,28}=0.212, P<0.649\right)$. The differences of BSC cover were significant $\left(F_{1,28}=17.17, P<0.0002\right)$. For Litter cover, the ANOVA test was not significant $\left(F_{1,28}=0.006, P<\right.$ 0.939). And for Bare soil cover the result indicated significant differences $\left(F_{1,28}=31.96, P<0.0001\right)$ (Figure 3$)$.

\section{Discussion}

\section{1. Plant community diversity}

Grazing gradient is widely used to understand the effect of grazing on plant species diversity and structure [35, $7,25]$. In our study, we ensured that environmental factors were homogeneous (slope, soil, exposure, elevation) and the only gradient is the effect of grazing activity. The composition of the pant community in the study area is characterized by the dominance of annuals (therophytes); this is consistent with the observation of [37], where therophytes dominate the Steppe rangelands of the Northern Africa. Our results indicated that annual forbs diversities were significantly different between grazed and protected areas; the exception is made for evenness that was not significant. Plant species diversity seems to be not affected by grazing for all grasses and shrubs for perennial forbs, species richness, Simpson index and Evenness were not significant, only Shannon diversity was significantly different between protected and grazed habitats.

Our results indicated that protection, increased annual species diversity, this can be due to the colonization of free gaps between vegetation patches. After protection from grazing, the competition for resources is attenuated and there is no disturbance by herbivores, this can have positive feedback on overall ecosystem health. Furthermore, the dominant species Stipa tenacissima can facilitate the establishment of other plant species. 


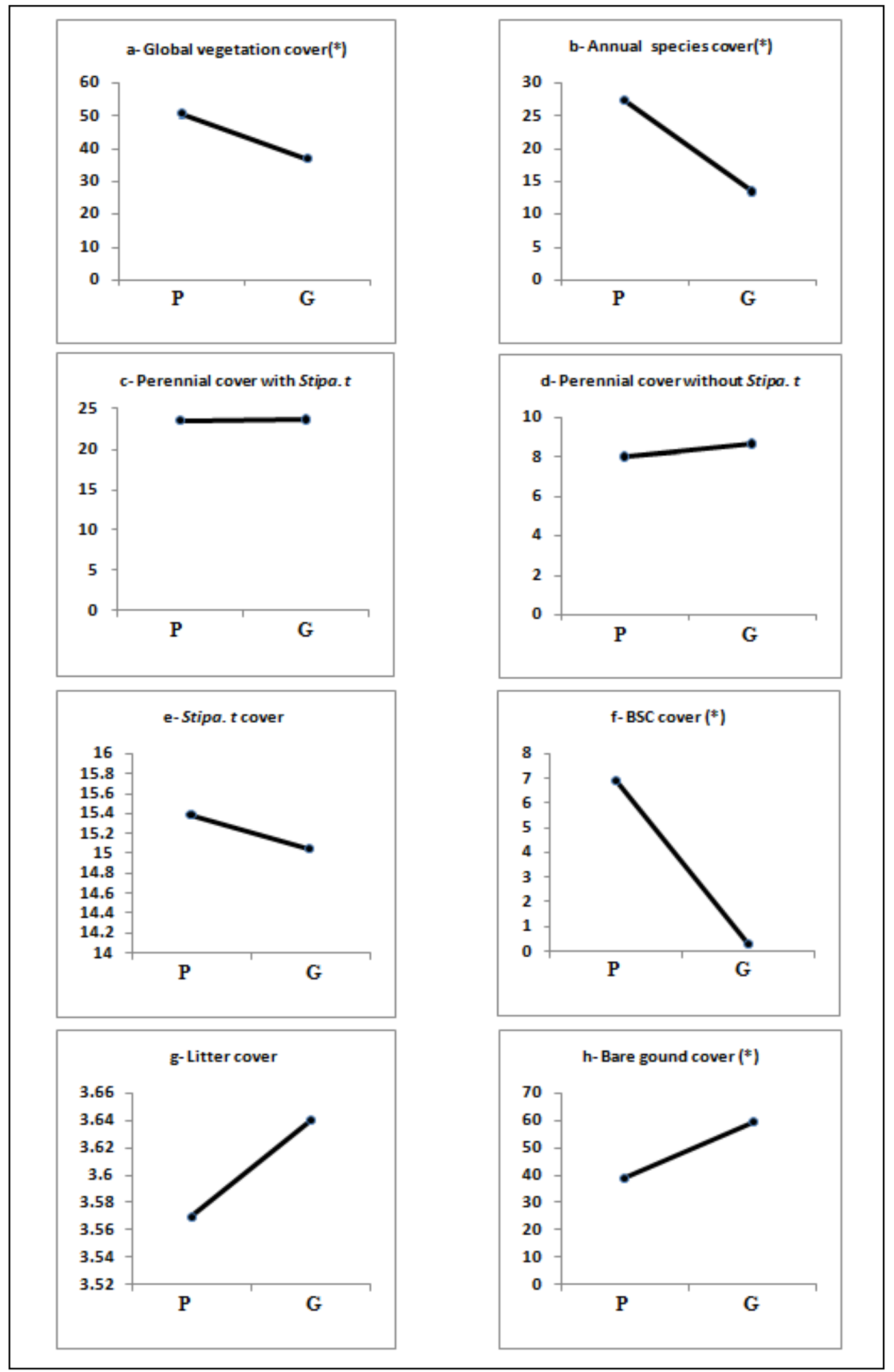

Figure 3: Cover rates of soil surface conditions, $(*)$ indicate significant differences of the ANOVA test between grazed and protected areas, $(\mathrm{P})$ protected, $(\mathrm{G})$ grazed.

These results are consistent with those of [38]. In addition, field observations indicated the co-occurrence (coexistence) of many plants with Alfa grass. The facilitative interactions of Stipa tenacissima has been reported previously in Mediterranean rangelands [39].

We found some species that are characteristic of degraded areas (Atractylis serratuloides, Noaea mucronata, and Peganum harmala, Centaurea sp.) $[40,18,12]$ within the protected areas, the results suggest that protected 
areas are grazed recently, or not protected for a long time. Indeed, these protected areas, are set enclosure for 3 to 4 years. After this period, the protected areas are open to grazing activity, according to an official decree of the administrative authorities. According to [41], the grazing season duration is 3 months and begins in April. Following weather conditions, another season occurs in autumn. High Commission for Development of the Steppe (HCDS) ensures the assessment of rangeland productivity. Although, species (Atractylis serratuloides, Noaea mucronata, and Peganum harmala, Centaurea sp.) are among less palatable species indicating land degradation [42], and even after the opening of protected areas, herbivores consume the most palatable and nutritious species [1], leaving the less palatable species. These species are considered as invasive species, with the high ability to produce seeds and colonize free spaces [40].

\section{2. Plant community structure}

The importance of vegetation cover lies not only in protecting the soil against wind and water erosion, but also, as a source of organic matter to maintain essential levels of nutrients for plant growth [43]. Soil structure is also maintained through the roots of various plants. Our results showed that the global vegetation cover was higher in protected areas compared to grazed ones; this is consistent with the finding of [12]. When we separated the total cover of vegetation to perennial cover and annual cover, only annual species cover showed a significant difference. Annual cover contributed by more than a half to the total cover of vegetation in protected areas. This finding highlights the importance of annual species in the composition of plant communities of arid steppe rangelands of Algeria. This suggests that annual cover can be a good indicator for the monitoring of vegetation health and overall ecosystem characteristics. This result is not in concordance with those of [12], indicating that annuals are not helpful as a structural component.

According to [40], steppe rangelands slightly degraded represent 20 to $40 \%$ of perennial vegetation cover, and 15 to $25 \%$ of the annual vegetation cover, represent steppe rangelands in good dynamic state. Our results showed $23 \%$ of perennial vegetation cover in both grazed and protected areas, which is slightly different about the threshold of $20 \%$ indicating degraded steppe. Stipa tenacissima is the most remarkable species in High Plaines of North African landscapes [44, 45]. The cover of Stipa tenacissima contributed greatly to the total perennial cover in protected areas with $65 \%$, and with $63 \%$ in grazed habitats, and did not show any significant differences between the two treatments. We can suggest that protection from grazing did not promote the development of perennials. However, other studies on steppe rangelands of Algeria e.g. $[5,22]$ indicated that protection from grazing increased the perennial cover.

BSCs are a complex mosaic of cyanobacteria, green algae, lichens, mosses, fungi and bacteria. BSCs have many important functions including the conservation of soil moisture, reduce soil erosion [46], the fixation of atmospheric nitrogen [47], carbon sequestration [48], seedlings installation [49, 50], and considered ecosystem functioning indicators [46]. Our results indicated that protection from grazing have a positive effect on the recovery of BSCs. The cover of BSCs was significantly different between grazed and protected areas. These results agree with previous studies, where BSCs coverage was reduced under the effect of grazing activity, including trampling [51, 52].

Litter is the main source of organic matter [53], reducing litter inputs can decrease the organic matter content in the soil [54] leading to soil degradation. We expected that protection from grazing would increase litter input, since dense vegetation reacts as a trap for litter [55]. However, litter cover did not indicate significant differences between the two treatments. It seems that the litter cover is maintained at a constant level, even after protection from grazing.

Bare ground cover can be used as an indicator of grazing pressure due to trampling [56]. We found that bare soil cover was higher under free grazing management compared to protected areas, this is consistent with results of [57, 11]. The importance of the bare soil surface can have an effect of wind erosion [58], as well as the increase in bare soil cover is considered as a degradation process [59]. These conditions are the results of grazing activity leading to desertification.

\section{Conclusion}

Plant community diversity and structure are important attributes of ecosystem assessment in arid steppe rangelands. Comparative studies of plant community diversity and structure along a grazing gradient can help answer crucial questions for ecosystem management. Our study appears to be effective in the detection of the most affected functional group by grazing, but this method can have limitation where diversity of groups is poor [60]. Plant community structure is found to be more sensitive than plant diversity to grazing activity; this is consistent with the results of [7]. Since the establishment of perennials is crucial for biological recovery [54], it's so far for us to conclude that the management applied in the studied area is effective, indicating that more 
protection is needed to meet the requested state of healthy ecosystems. We can conclude that the study of cover parameters is a good indicator to detect the change in the arid steppe rangelands.

Acknowledgments- This work is funded by the National Fund for Research (FNR), via the Centre for Scientific and Technical Research in the Dry Areas (CRSTRA), we thank the High Commissariat for the Development of Steppe (HCDS) for their technical support. We are grateful to the anonymous referees for their helpful comments and suggestions to improve the quality of the manuscript.

\section{References}

1. Le Floc'h E ., Bocconea,13 (2001) 223.

2. Jacobo E.J., Rodríguez A.M., Bartoloni N., Deregibus V.A., Rangel. Ecol. Manag, 59 (2006) 249.

3. Quézel P., Réflexions sur l'évolution de la flore et de la végétation au Maghreb méditerranéen, Ibis Press. Paris (2000).

4. Slimani H., Aidoud A., Environmental Challenges in the Mediterranean 2000-2050. In: Marquina A ed. Environmental Challenges in the Mediterranean 20002050. Springer Netherlands, Dordrecht, (2004) 93.

5. Aidoud A.,Touffet J., Sécheresse, 7 (1996) 187.

6. Alados C.L., El Aich A., Papanastasis V.P., Ozbek H., Navarro T., Freitas H., Vrahnakis M., Larrosi D., Cabezudo B., Ecol. Modell, 180 (2004) 523.

7. Pueyo Y., Alados C.L., Ferrer-Benimeli C., J. Arid Environ, 64 (2006) 698.

8. Attia W., Tarhouni M., Ouled Belgacem A., Gammar O., Khatteli H., Afr. J. Ecol, n/a-n/a. (2013)

9. Saiz H., Alados C.L., Acta Oecologica, 59 (2014) 18.

10. Milchunas D.G., Sala O.E., Lauenroth W.K., Am. Nat, 132 (1988) 87.

11. Alhamad M.N., Alrababah M.A., Bataineh M. M., Al-Horani A.S., Plant Ecol, 196 (2008) 289.

12. Hirche A., Salamani M., Abdellaoui A., Benhouhou S., Valderrama J.M., Environ. Monit. Assess, 179 (2011) 403.

13. Amghar F., Forey E., Margerie P., Langlois E., Brouri L., Kadi-Hanifi H., Rev. D Ecol. Terre La Vie, 67 (2012) 257.

14. Gamoun M., J. Arid Land, 6 (2013) 324.

15. Noor Alhamad M., J. Arid Environ, 66 (2006) 698.

16. Zuo X., Zhao H., Zhao X., Guo Y., Yun J., Wang S., Miyasaka T., Environ. Geol, 58 (2008) 1227.

17. Rubio J.L., Bochet E., J. Arid Environ, 39 (1998) 113.

18. Slimani H., Aidoud A., Rozé F., J. Arid Environ, 74 (2010) 685.

19. Le Houérou H.N., J. Arid Environ, 48 (2001) 103.

20. Myers N., Mittermeier R.A., Mittermeier C.G., da Fonseca G.A.B.,Kent J., Nature, 403 (2000) 853.

21. Schröter D., Cramer W., Leemans R., Prentice I.C., Araújo M.B., Arnell N.W., Bondeau A., Bugmann H., Carter T.R., Gracia C.A., de la Vega-Leinert A.C., Erhard M., Ewert F., Glendining M., House J.I., Kankaanpää S., Klein R.J.T., Lavorel S., Lindner M., Metzger M.J., Meyer J., Mitchell T.D., Reginster I., Rounsevell M., Sabaté S., Sitch S., Smith B., Smith J., Smith P., Sykes M.T., Thonicke K., Thuiller W., Tuck G., Zaehle S., Zierl B., Science, 310 (2005) 1333.

22. Salemkour N., Aidoud A., Chalabi K., Chefrour A., Rev. D Ecol. Terre La Vie, 71 (2016) 178.

23. Firincioglu H.K., Seefeldt S.S., Şahin B., Environ. Manage, 39 (2007) 326.

24. Hoshino A., Yoshihara Y., Sasaki T., Okayasu T., Jamsran U., Okuro T.,Takeuchi K., J. Arid Environ, 73 (2009) 687.

25. Hanke W., Böhner J., Dreber N., Jürgens N., Schmiedel U., Wesuls D., Dengler J., Ecol. Appl, 24 (2014) 1188.

26. Halitim A., Sols des régions arides d'Algérie, OPU. Alger (1988)

27. Hammouda R., Huguenin J., Nedjraoui D., Régression des parcours et adaptation des élevages en zone steppique algérienne, in: Renc. Rech. Ruminants, 20 (2013) 299.

28. Goodall D.W., Australian Aust. J. Sci. Res. B, 5 (1952) 1.

29. Quézel P., Santa S., Nouvelle flore d'Algérie et des régions désertiques méridionales. Vol 1. CNRS Paris. (1962).

30. Quézel P., Santa S., Nouvelle flore d'Algérie et des régions désertiques méridionales. Vol 2. CNRS. Paris. (1963).

31. Magurran A., Measuring Biological Diversity. Blackwell Publishing Ltd, Oxford, UK (2004).

32. Shannon, C.E., Bell Syst. Tech. J, 27 (1948) 379.

33. Pielou, E.C., Journal of Theoretical Biology, 13 (1966) 131.

34. R Development Core Team, R: A language and environment for statistical computing. R foundation for 
statistical computing, Vienna, Austria. http://www.R-project. org. (2016)

35. Metzger K.L., Coughenour M.B., Reich R.M., Boone R.B., J. Arid Environ, 61 (2005) 147.

36. Aidoud A., Le Floc'h E., Le Houerou H.N., Sécheresse, 17 (2006) 19.

37. Benaraj A., Boucherti H., Mederbal K., Benabdeli K., Baghdadi D., J. Mater. Environ. Sci, 2 (S1) (2011) 564.

38. Luzuriaga A.L., Sánchez A.M., Maestre F.T., Escudero A., PloS one, 7 (2012) e41270.

39. Maestre F.T., Bautista S., Cortina J., Ecology, 84 (2003) 3186

40. Le Houérou H.N., Options Méditerranéennes Série B. Etudes Rech, 10 (1995) 1.

41. Saidi S., Gintzburger G., Rangel. J, 35 (2013) 47.

42. Bechchari A., El Aich A., Mahyou H., Baghdad B., Bendaou M., J. Mater. Environ. Sci, 5 (S2) (2014) 2572.

43. Maestre F.T., Cortina J., Proc. Biol. Sci, 271 Suppl 5 (2004) S331.

44. Aidoud A., Sécheresse, 7 (1996) 187.

45. Kaabeche M., Acta Bot. Gall, 143 (1996) 85.

46. Bowker M.A., Miller M.E., Belnap J., Sisk T. D., Johnson N.C., Conserv. Biol, 22 (2008) 1533.

47. Rychert R.C., Skujiņš J., Soil Sci. Soc. Am. J, 38 (1974) 768.

48. Housman D.C., Powers H.H., Collins A.D., Belnap J., J. Arid Environ, 66 (2006) 620.

49. Li X.R., Jia X.H., Long L.Q., Zerbe S., Plant Soil, 277 (2005) 375.

50. Langhans T.M., Storm C., Schwabe A., Flora - Morphol. Distrib. Funct. Ecol. Plants, 204 (2009) 157.

51. Liu H., Han X., Li L., Huang J., Liu H., Li X., Rangel. Ecol. Manag, 62 (2009) 321.

52. Gomez D.A., Aranibar J.N., Tabeni S., Villagra P.E., Garibotti I.A., Atencio A., Acta Oecologica, 38 (2012) 33.

53. Li X.R., Jia X.H., Dong G.R., J. Arid Environ, 64 (2006) 505.

54. Le Houérou H.N., Arid L. Res. Manag, 16 (2002) 1.

55. Linstädter A., Baumann G.,Catena, 103 (2012) 3.

56. Joubert L., Pryke J.S.,Samways M.J., South African J. Bot, 92 (2014) 126.

57. Alrababah M.A., Alhamad M.A., Suwaileh A., Al-Gharaibeh M., Appl. Veg. Sci, 10 (2007) 257.

58. D'Odorico P., Davis K.F., Runyan C.W., Bhattachan A., Ravi S., Adv. Water Resour, 51 (2012) 326.

59. Verón S.R., Paruelo J.M., J. Appl. Ecol, 47 (2010) 1233.

60. James M.B., Joe F., Mark J.S., Jonathan S., Sarah J.C., Steve J.G., Richard T., J. Appl. Ecol, 38 (2001) 253.

Appendix 1. List of plant species recorded in the study area, and their life span, growth form, biological span, frequency (number of transects), and treatment (species occurring in protected areas, grazed areas, or common species).

\begin{tabular}{|c|c|c|c|c|c|}
\hline Scientific name & Life span & Growth form & Raunkiaer types & Frequency & Treatment \\
\hline Adonis dentata & Annual & Forb & Therophyte & 1 & Protected \\
\hline Aizoon hispanicum & Annual & Forb & Therophyte & 1 & Common \\
\hline Allium cupani & Perennial & Forb & Geophyte & 1 & Common \\
\hline Alyssum parviflorum & Annual & Forb & Therophyte & 1 & Common \\
\hline Ammoides verticillata & Annual & Forb & Therophyte & 1 & Protected \\
\hline Anacyclus cyrtolepidioides & Annual & Forb & Therophyte & 1 & Common \\
\hline Anabasis articulata & Perennial & Shrub & Chamaephyte & 1 & Common \\
\hline Argyrolobium uniflorum & Perennial & Forb & Chamaephyte & 1 & Common \\
\hline Aristida plumosa & Perennial & Grass & Hemicryptophyte & 1 & Grazed \\
\hline Artemisia campestris & Perennial & Shrub & Chamaephyte & 1 & Common \\
\hline Artemisia herba-alba & Perennial & Shrub & Chamaephyte & 2 & Common \\
\hline Asparagus albus & Perennial & Shrub & Chamaephyte & 1 & Protected \\
\hline Asteriscus pygmaeus & Annual & Forb & Therophyte & 2 & Common \\
\hline Astragalus cruciatus & Annual & Forb & Therophyte & 1 & Protected \\
\hline Atractylis cancellata & Annual & Forb & Therophyte & 1 & Common \\
\hline Atractylis delicatula & Perennial & Forb & Chamaephyte & 2 & Protected \\
\hline Atractylis prolifera & Annual & Forb & Therophyte & 3 & Protected \\
\hline Atractylis serratuloides & Perennial & Forb & Chamaephyte & 1 & Common \\
\hline
\end{tabular}




\begin{tabular}{|c|c|c|c|c|c|}
\hline Avena barbata & Annual & Grass & Therophyte & 2 & Protected \\
\hline Avena sterilis & Annual & Grass & Therophyte & 1 & Protected \\
\hline Brachypodium distachyum & Annual & Grass & Therophyte & 3 & Common \\
\hline Bromus rubens & Annual & Grass & Therophyte & 2 & Common \\
\hline Bupleurum semicompositum & Annual & Forb & Therophyte & 2 & Common \\
\hline Calendula aegyptiaca & Annual & Forb & Therophyte & 2 & Protected \\
\hline Carduus chevallieri & Annual & Forb & Therophyte & 2 & Protected \\
\hline Catapodium loliaceum & Annual & Grass & Therophyte & 3 & Grazed \\
\hline Centaurea acaulis & Perennial & Forb & Hemicryptophyte & 6 & Protected \\
\hline Centaurea incana & Perennial & Forb & Hemicryptophyte & 1 & Protected \\
\hline Centaurea tenuifolia & Perennial & Forb & Hemicryptophyte & 2 & Protected \\
\hline Centaurea omphalotricha & Annual & Forb & Therophyte & 3 & Protected \\
\hline Chrysanthemum coronarium & Annual & Forb & Therophyte & 5 & Protected \\
\hline Cutandia dichotoma & Annual & Grass & Therophyte & 3 & Grazed \\
\hline Dactylis glomerata & Perennial & Grass & Hemicryptophyte & 2 & Protected \\
\hline Ebenus pinnata & Annual & Forb & Therophyte & 2 & Protected \\
\hline Echinaria capitata & Annual & Grass & Therophyte & 9 & Protected \\
\hline Echium pycnanthum & Annual & Forb & Therophyte & 4 & Common \\
\hline Eremopyrum cristatum & Perennial & Grass & Hemicryptophyte & 5 & Common \\
\hline Erodium glaucophyllum & Perennial & Forb & Hemicryptophyte & 4 & Protected \\
\hline Erodium triangulare & Annual & Forb & Therophyte & 4 & Common \\
\hline Eruca vesicaria & Annual & Forb & Therophyte & 4 & Common \\
\hline Euphorbia falcata & Annual & Forb & Therophyte & 5 & Common \\
\hline Evax pygmaea & Perennial & Forb & Hemicryptophyte & 1 & Grazed \\
\hline Filago germanica & Annual & Forb & Therophyte & 2 & Protected \\
\hline Filago spathulata & Annual & Forb & Therophyte & 4 & Common \\
\hline Fumana ericoides & Perennial & Forb & Chamaephyte & 3 & Grazed \\
\hline Genista microcephala & Perennial & Shrub & Nanophanerophyte & 3 & Protected \\
\hline Hedypnois rhagadioloides & Annual & Forb & Therophyte & 4 & Common \\
\hline Helianthemum lippii & Perennial & Shrub & Therophyte & 7 & Common \\
\hline Helianthemum salicifolium & Annual & Forb & Therophyte & 3 & Common \\
\hline Herniaria fruticosa & Perennial & Forb & Hemicryptophyte & 3 & Common \\
\hline Hippocrepis multisiliquosa & Annual & Forb & Therophyte & 6 & Protected \\
\hline Iris sisyrinchium & Perennial & Forb & Geophyte & 2 & Common \\
\hline Juniperus phoenicea & Perennial & Shrub & Phanerophyte & 1 & Grazed \\
\hline Koelpinia linearis & Annual & Forb & Therophyte & 2 & Common \\
\hline Koeleria pubescens & Annual & Grass & Therophyte & 10 & Common \\
\hline Launaea resedifolia & Annual & Forb & Therophyte & 9 & Common \\
\hline Launaea arborescens & Perennial & Shrub & Chamaephyte & 5 & Protected \\
\hline Lithospermum apulum & Annual & Forb & Therophyte & 11 & Protected \\
\hline Lolium rigidum & Annual & Grass & Therophyte & 8 & Protected \\
\hline Lygeum spartum & Perennial & Grass & Geophyte & 3 & Grazed \\
\hline Malva aegyptiaca & Annual & Forb & Therophyte & 12 & Common \\
\hline Matthiola maroccana & Perennial & Forb & Hemicryptophyte & 4 & Common \\
\hline Medicago hispida & Annual & Forb & Therophyte & 10 & Common \\
\hline Medicago laciniata & Annual & Forb & Therophyte & 13 & Protected \\
\hline Medicago minima & Annual & Forb & Therophyte & 9 & Protected \\
\hline Micropus bombycinus & Annual & Forb & Therophyte & 3 & Common \\
\hline Minuartia campestris & Annual & Forb & Therophyte & 11 & Common \\
\hline Noaea mucronata & Perennial & Shrub & Chamaephyte & 3 & Common \\
\hline
\end{tabular}




\begin{tabular}{|c|c|c|c|c|c|}
\hline Papaver hybridum & Annual & Forb & Therophyte & 12 & Protected \\
\hline Paronychia capitata & Perennial & Forb & Hemicryptophyte & 8 & Common \\
\hline Peganum harmala & Perennial & Forb & Hemicryptophyte & 9 & Protected \\
\hline Pituranthos scoparius & Perennial & Forb & Chamaephyte & 4 & Common \\
\hline Plantago albicans & Perennial & Forb & Hemicryptophyte & 5 & Common \\
\hline Plantago ovata & Annual & Forb & Therophyte & 13 & Common \\
\hline Plantago psyllium & Annual & Forb & Therophyte & 3 & Common \\
\hline Poa bulbosa & Perennial & Grass & Hemicryptophyte & 12 & Common \\
\hline Pseuderucaria teretifolia & Annual & Forb & Therophyte & 12 & Protected \\
\hline Reichardia tingitana & Annual & Forb & Therophyte & 11 & Common \\
\hline Reseda alba & Annual & Forb & Therophyte & 14 & Protected \\
\hline Reseda luteola & Annual & Forb & Therophyte & 7 & Protected \\
\hline Rochelia disperma & Annual & Forb & Therophyte & 2 & Protected \\
\hline Salsola vermiculata & Perennial & Shrub & Chamaephyte & 8 & Common \\
\hline Scabiosa arenaria & Annual & Forb & Therophyte & 15 & Common \\
\hline Scabiosa maritima & Annual & Forb & Therophyte & 13 & Protected \\
\hline Scabiosa stellata & Annual & Forb & Therophyte & 8 & Common \\
\hline Schismus barbatus & Annual & Grass & Therophyte & 4 & Common \\
\hline Scorzonera undulata & Annual & Forb & Therophyte & 20 & Protected \\
\hline Sedum sediforme & Perennial & Forb & Hemicryptophyte & 16 & Common \\
\hline Salvia verbinaca & Perennial & Forb & Hemicryptophyte & 14 & Protected \\
\hline Sideritis montana & Annual & Forb & Therophyte & 15 & Protected \\
\hline Silene rubella & Annual & Forb & Therophyte & 20 & Protected \\
\hline Silene tridentata & Annual & Forb & Therophyte & 16 & Common \\
\hline Spergularia diandra & Annual & Forb & Therophyte & 19 & Protected \\
\hline Stipa lagascae & Perennial & Grass & Hemicryptophyte & 16 & Common \\
\hline Stipa tenacissima & Perennial & Grass & Hemicryptophyte & 30 & Common \\
\hline Stipa tortilis & Annual & Grass & Therophyte & 26 & Common \\
\hline Teucrium polium & Perennial & Forb & Chamaephyte & 20 & Common \\
\hline Thymelaea hirsuta & Perennial & Shrub & Chamaephyte & 30 & Protected \\
\hline Thymelaea microphylla & Perennial & Shrub & Chamaephyte & 21 & Common \\
\hline Vella аппиа & Annual & Forb & Therophyte & 29 & Common \\
\hline Xeranthemum inapertum & Annual & Forb & Therophyte & 30 & Grazed \\
\hline
\end{tabular}

\section{(2017) ; http://www.jmaterenvironsci.com}

